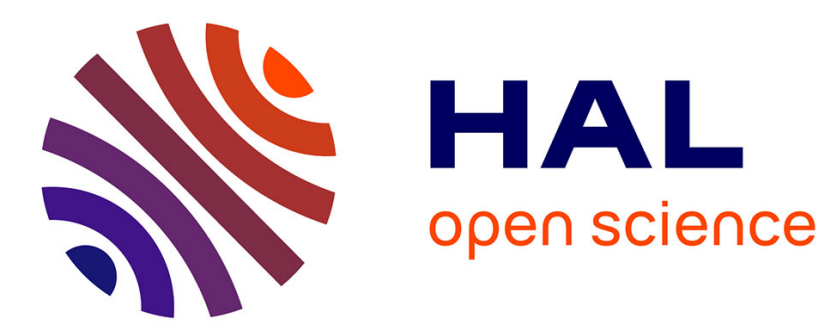

\title{
Mutation Carriers : led by Spaniards in U.S. Laboratories in the early $80 \mathrm{~s}$
}

\author{
Enrique Wulff Barreiro, E. Currás
}

\section{To cite this version:}

Enrique Wulff Barreiro, E. Currás. Mutation Carriers: led by Spaniards in U.S. Laboratories in the early 80s. Bulletin d'histoire et d'épistémologie des sciences de la vie , 2012, 19 (1), pp.45-65. hal-00879538

\section{HAL Id: hal-00879538 \\ https://hal.science/hal-00879538}

Submitted on 4 Nov 2013

HAL is a multi-disciplinary open access archive for the deposit and dissemination of scientific research documents, whether they are published or not. The documents may come from teaching and research institutions in France or abroad, or from public or private research centers.
L'archive ouverte pluridisciplinaire HAL, est destinée au dépôt et à la diffusion de documents scientifiques de niveau recherche, publiés ou non, émanant des établissements d'enseignement et de recherche français ou étrangers, des laboratoires publics ou privés. 
Bull. Hist. Épistém. Sci. Vie, 2012, 19, (1), 45 - 65

Mutation Carriers : led by Spaniards in U.S. Laboratories in the early $80 s^{*}$

Enrique Wulff Barreiro et Emilia Curras ${ }^{* *}$

RESUME. L'histoire des recherches initiales visant à transférer des produits génétiques induisant des tumeurs fut grandement facilitée par la - disponibilité de lignées cellulaires indéfiniment multipliables s'inhibant par
contact entre elles (NTH 3T3). Durant les années 70, l'enseignement de ceux qui participaient à ces recherches parvint à certains biologistes espagnols récemment arrivés aux Etats-Unis. Dans les années 80, un groupe importan de cancérologues espagnols élaborèrent des techniques sophistiquées pour la détection des oncogènes, comprenant le clonage génétique de régions où existaient des aberrations, le séquençage et l'identification de gènes structuraux dans les loci affectés, ainsi que la détermination de leur rôle dans le cancer. Pellicer travailla de 1976 à 1980 sur la prolifération des cellules et le cancer. Pellicer travailla de 1976 à 1980 sur la prolifération des celluies et
le cancer au Medical Center de l'Université de Columbia. Manuel Perrucho se rendit à une Gordon Conference sur l'Immunologie à New York. Angel Perricer lui communiqua les résultats de ses transfections. C'est pourquo Perrucho quitta l'Institut Max Planck de Génétique Moléculaire de Berlin pour le CSHL américain puis plus tard pour Stony Brook. C'est également en 1979 que Mariano Barbacid, du Laboratoire des tumeurs virales ARN, NCI Bethesda, se rendit à New York, où Angel Pellicer luí communica les Bethesda, se rendit à New York, ou Angel Pellicer lui communica les
résultats de ses transfections. Ces trois leaders de la recherche en cancérologie se concentrèrent sur l'oncogène. Après l'observation initiale qu'une proportion significative des tumeurs positives dans les fibroblastes utilisés - les cellules NIH 3T3 - et que les gènes responsables appartenaient à la famille ras. Angel Pellicer isola les deux principaux gènes murins responsables pour le phénotype, $\mathrm{N}$-ras, dans se résultats présentés en 1984. L'année suivante il séquença l'entière région codante de $N$-ras, et avança des

-A version of this paper was a contribution to: 4 th International Conference of the European Society for the History of Science (Barcelona, Nov. 2010).

** Enrique Wulff Barreiro. Consejo Superior de Investigaciones Cientificas.

Emilia Currás. Universidad Autónoma de Madrid. 
preuves du spectre de mutations activees dans diverses lignees de souris par différents agents. Un grand nombre de facteurs méthodiques entrent en jeu dans cetre serie historique de découvertes Des symboles conceptuels decoulant de la vision performances concurcentes, metent en evidence le passge de leurs auteurs de l'Université de Columbia au Laboratoire de Cold Spring Harbor et au Frederick Cancer Research Center.

***

ABSTRACT. The history of the initials protocols to transfer viral genetic products inducing tumors was greatly facilitated by the availability of continuous cell line of highly contact-inhibited cells (NIH/3T3). During the $70^{s}$ the teachings of those involved in this research reached some of the recent arrived in the US Spanish biologists. And in the early $80^{5}$ a significan group of Spanish oncologists developed laborious techniques for the detection of oncogenes, involving the gene cloning of regions where are aberrations, sequencing and identification of structural genes in the affected loci and then dete in cell proliferation \& cancer at the Columbia University's Medical Center, College of Physicians and Surgeons. In 1979, Manuel Perucho went to Gordon Conference on Immunology in New York. Ángel Pellicer communicated him, his transfection results. It was the why Perucho moved away from Berlin Max Planck Institut fur Molekulare Genetik to US CSHL and later to Stony Brook. Also in 1979. Mariano Barbacid, from the Laboratory of RNA Tumor Yiruses, NCI, Bethesda went to New York, where Ángel Pellicer communicated him his transfection results. These three molecular oncology research leaders met with oncogene. After the initial observation that a significant proportion of the tumors scoring positive in the fibroblasts used - the NIH 3T3 cells - and that the genes responsible belonged to the ras family, Angel Pellicer isolated the two main murine genes responsible for the phenotype, $\mathrm{N}$-ras, in results presented in 1984. The following year he sequenced the complete coding region of $\mathrm{N}$-ras, and suggested evidence for the spectrum of activated mutations in different mouse strains and by different agents. A number of methodical factors affect this historical series of performances. Concept symbols derived from the display of the graphical distribution along time of the concurrent performances, reveal the successive shifts of their authors from the Columbia University to the Cold Spring Harbor Lab and the Frederick Cancer Research Center.

\section{INTRODUCTION}

In a first approach, the integrated interaction of the viral and cellular genomes is due to L.A. Zilber (1894-1966), ${ }^{1}$ the theory of oncogenes was originated by R. Huebner (1914-1998) and G. Todaro $(1937-),{ }^{2} \mathrm{H}$. Temin (1934-1994) elaborated the theory of the provirus D. Baltimore (1938-) isolated the enzyme transcriptase inverse, and M. Barbacid (1949-) activated the first oncogene. ${ }^{4}$ The most accurate reconstruction from the true ancestral cancer immunologist Zilber, may take into account of the importance of the use of cell lines free of sarcoma virus in mutagenic experiments.

In 1969, was segregated the third line 3T3, from the mice embryos in the Swiss/NIH line. This line was to be called NIH 3T3 (after the name of the National Institute of Health where they proliferated). One of the authors was Todaro. The cells gave 20-25 steps to be cloned - until achieving the clone (clone 6) with a particularly high plating efficiency and low saturation density. ${ }^{5}$ Later the NIH 3 T3 was used mainly to study the viral transformation in tissue- and cell- cultures. The selection of this line for transfection experiments is conditioned by a high efficiency in the integration and fixation of the exogenous DNA in the genome of the NIH 3 T3 cells.

The considerable interest that had the discovery that an ample variety of tumor cells contained activated ras genes, was detectable

Lev Zilber (1894-1966) contribution, L. Sifber, 'Ueber das Wesen der WeilFelixschen Reaktion', Centralbl, f. Bakt. etc. 1. Abt. Originale (1923), 89, 250-9, where is proved the serological modification experienced by the bacteria Proteus vulgaris, hereditary transformed into a variant that is agglutinated by the serum of the guinea pig infected by louse-borne typhus virus. It was a precedent of the experiments by Griffith on the transformation of pneumococci by way of transfer from a virulent culture, see F. Griffith, 'The Significance of Pneumococcal Types', Joumal of Hygiene (1928), 27, 113

R.J. Huebner, G.J. Todaro, 'Oncogenes of RNA tumor viruses as determinants of cancer', Proc Natl Acad Sci U S A. (1969), 64, 1087-94.

Max Herzberg, Michel Revel, Atlas de biologie moléculaire. Hermann, 1972.

${ }^{4}$ S.J. Garte, A.E. Hochwalt, Oncogene activation of experimental carcinogenesis: the role of carcinogen and tissue specificity', Environmental Health Perspectives (1989), $81,29-31$.

J.L. Jainchill, S.A. Aaronson, G.J. Todaro, 'Murine sarcoma and leukermia viruses: assay using clonal lines of contact-inhibited mouse cells', Journal of Virology (1969), $4,549-553,550$. 
through gene transfer in NIH 3T3 cells, and displayed the work by Barbacid in August 1983. ${ }^{6}$ It reports on the c-has/bas human protooncogene spontaneous activation along the transfection of NIH/3T3 cells, a fact that occurred without the participation of known carcinogenic agents. The explanation of this event was obstaculized by the limited knowledge of the biochemical properties of the protein p2l secondary and terciary structures. This protein, codified by the chas/ras gene, spontaneously activated, will incorporate aspartic acid as a $12^{\text {th }}$ amino acid residue. Even more, the adequate coupling of the alpha-helicoidal structure at the amino terminal domain of the ras proteins, is altered by a conformational change after the replacement of the $12^{\text {th }}$ amino acid residue (Gly) by any other amino acid residue (except proline). This mechanism of malign activation of the ras oncogene, will be further supplemented by the discovery, also by Barbacid and also by studying the morphological transformation of the NIH 3 T 3 cells, of the amplification mechanics of the ras gene as an alternative path through which the ras gene can participate in the development of human neoplasia.

This work was presented to the US Natl Acad Sci on April 1983 by the 1953 Nobel Prize, Severo Ochoa, who also selected to present there on July 1985 a development on human adenocarcinoma cells of previous NIH 3T3 results, associated to the detection of point mutations authored by M. Perucho. ${ }^{89}$ The point mutation malignant acquisition responsibility discovery was the why after which Barbacid was awarded in $1988,{ }^{10}$ but a carcinogenic induction of ras oncogene

${ }^{6}$ E. Santos, E.P. Reddy, S. Pulciani, R.J. Feldmann, M. Barbacid, 'Spontaneous activation of a human proto-oncogene', Proc Nati ACad Sci USA (1983), 80, 4679-83. ' S. Puiciani, E. Santos, L.K. Long, V. Sorrentino, M. Barbacid, 'ras Gene amplification and malignant transformation', Moll Cell Biol (1985), 5, 2836-41.

${ }^{8}$ E. Winter, F. Yamamoto, C. Almoguera, M. Perucho, 'A method to detect and characterize point mutations in transcribed genes: Amplification and overexpression of the mutant c-Ki-ras allele in human tumor cells', Proc Natl Acad Sci USA (1985), $82,7575-9$

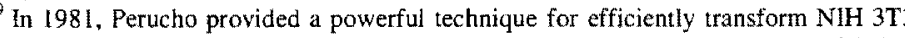
cells, see M. Perucho, M. Goldfarb, K. Shimizy, C. Lama, J. Fogh, M. Wigler, 'Human-tumor-derived cell lines contain common and different transforming genes' Cell $(1981), 27,467-76$

The "cancer Nobel" was attributed (in 1988) by the Switzerland Josef Steine Foundation to Barbacid "for providing evidence that the interaction of a carcinogen activation was also obtained under the respongbility of A. Pellicer, being I. Guerrero his postdoc. ${ }^{11}$

Angel Pellicer, professor in the NYU Dpt of Pathology from 1980, worked with animal model systems of carcinogenesis, by using ras genes because of his great clinical relevance. Constantly in contact with Spain through the training of postdocs, he admitted Isabel Guerrero as a Fellow of the Spanish High Research Council in 1983. ${ }^{12}$ The discovery was that a significant proportion of the tumors scored positive in the NIH 3T3 focus forming assay, and the genes responsible belonged to the ras family. After the initial observation, the two main murine genes responsible for the phenotype, $N$-ras and $\mathrm{K}$-ras were quickly identified. The following year Pellicer sequenced the complete coding region of $\mathrm{N}$-ras, identified the activating mutation and indicated that in some tumors there was loss of the normal allele, suggesting that the wild type copy (proto-oncogene) was exerting some restraining effect on the action of the activated version (oncogene). Further studies continued providing evidence for the spectrum of activating mutations in different mouse strains and by different carcinogenic agents.

The Spanish team with which M. Barbacid solved the question that served to establish the molecular basis of human neoplasia was formed by E. Santos. D. Martin Zanca, and V. Notario. The Spanish researchers group where worked A. Pellicer involved V. Corces, A. Pellicer, P. Calzada, A. Villasante and I. Guerrero. M. Perucho by with a ras-proto-oncogene creates the event that initiates tumor formation", see E.P. Reddy, R.K. Reynolds, E. Santos, M. Barbacid. 'A point mutation is responsible for the acquisition of transforming properties by the T24 human bladder carcinoma', Nature (1982), 300, 149-52. For a medeulous figure depicting the importance of this last paper see M. Morange, "From the regulatory vision of cancer to the oncogene paradigm, 1975-1985. .. Hist. Biol. (1997), 30, 1-29, 21, Fig.

Pillasante, V. Corces, A. Pellicer, 'Activation of a c-K-ras oncogene by somatic mutation in mouse lymphomas induced by gamma radiation', Science (1984), 225, 1159-62.

Other postdoctorals with prof. Pellicer have been Claudette Boni, Alfredo Villasante, Javier Leon, Elizabeth Newcomb, Joan Berman, Timothy Thomson, Montserrat Corominas, Ramon Mangues, Renata Schiavo, Guillermo Saez, Rosario Oiva, Javier Santos, Antonio Garcia-Espana, Juan Sanchez-Arias. Marcos Malumbres, Neus Fener, Su-Ying Lu, Quixia Lan, Inmaculada Hernandez, Yixing Li, Ignacio Perez de Castro, Laura Martello-Rooncy, Marta Benet, and Raffi Suzme. 


\section{$+51$}

working with a team that included as Spanish collaborators $\mathrm{C}$. Almoguera, C. Lama and J. Jordano afforded with the characterization of human and murid cellular oncogenes and provided a method to detect mutations in transcripted genes. A previous paper reported on the constitutional history of these three groups. ${ }^{13}$

But all these experiments arrived to function just because of the fortunated circonstance, that the NIH3T3 cells were not normal at all, but that they already have accumulated a great number of genetic alterations subjacent to the gradual process of neoplastic transformation. They need one last push, provided by the dominant oncogene.

\section{METHODOLOGY}

Despite the phylogenetic analysis creates the text tradition that results in the production of critical editions of major written works, a trifling difficulty arises when what is wanted is to see if it works to retrace the history of a scientific program. ${ }^{14} \mathrm{~A}$ cladistic approach has been useful to give a quick indication of the likelihood relationships of Angel Pellicer in the race between the three concurrent Spanish teams.

Because the construction and characterization of a bibliographic library for mapping a given field, illustrates the tendency of action to develop where there is action already. And that its cohesiveness mainly depends on how old it is. A graphic presentation of the time series displayed by the papers which may be relevant to a topic is a preliminary analysis to determine what to make in terms of chronology. As the important paper for 3T3 cells was the choice of the precursors G.J. Todaro and $\mathrm{H}$. Green ${ }^{15}$, a highly cited collection of source records making reference to this original contribution was first considered.

${ }^{13}$ E. Currás, E. Wulff Barreiro, 'Integration in Europe of human genetics results obtained by Spaniards in the USA: a historical perspective', Scientometrics (2008), 75, $473-93$

${ }^{14}$ M. Spencer, E.A. Davidson, A.C. Barbrook, C.J. Howe, 'Phylogenetics of artificial manuscripts', Journal of Theoretical Biology (2004), 227, 503-11.

${ }^{5}$ G.J. Todaro, H. Green. 'Quantitative studies of growth of mouse embryo cells in culture and their development into established lines', Journal of cell biology (1963), $17,299-313$.
An analysis of the 'Science Citation Index' has determined us to consider the evolution of the number of citations of the main experiments involved. Owing to that, a reference analysis was made to induce the Price index (percentage references dated in last five years) of a selected set of A. Pellicer.

3 T3 CELLS, A TOOL FOR THE JOB

Testing for transforming activity by isolating viral DNA from cells that have been infected with a tumor pathogen is a function of the sort of cells used. Not many cells express, and absorb foreign DNA. But such are the NIH 3 T3 cells, an all-purpose line of skin like cells, from the US National Institutes of Health. It could be a marked contribution to the present-day objectives methodological approaches for analysis of infections by screening for signs for active virus, if it - was not a bright support to put foreign genes into cells by circumventing all the complexities of pathogens. The difference is that it is the calcium messenger system that ushers in the alien gene, not a virus. ${ }^{16}$

The outcome of exploring the $3 T 3$ cell type, comes to discuss on the questionable views related to their origins. ${ }^{17}$ And as it has been successfully applied to detect mutated cellular KRAS oncogenes in human tumors, and single mutations in the human and in the mouse genes, ${ }^{18}$ it can be described as a tool for the job of mutation genes, ${ }^{19}$ can be described as a tool for the job of mutation
detection. cellular level, has something truly Darwinian in character. ${ }^{20}$ This most prolific cell line for virus oncogenic essays, 3T3, was created to shape

${ }^{16}$ This replies the (according to Marx extremely fruifful for the history of science notion of action as describing the situational limit that grounds the most general differentiating characteristics between natural and technological sciences.

${ }^{17}$ R.S. Barkan, N.N. Nikol'skii, 'Minimally transformed 3T3 cell lines as an object for research on the mechanisms of proliferation', Tsitologiza (1985), 27, 5-27.

research on the mechanisms of proliferation', Tsitologiia (1985), 27, 5-27. M. Perucho, Analysis of genetic variability and maping of point mutations in influenza virus by the RNase A mismatch cleavage method', Proc Noth Acad sci USA (2004), 85, 3522-26.

${ }_{19}$ R.G. Cotton, 'Current methods of mutation detection', Mutat Res. (1993), 285, 125 44.

W. Anderson, M. Jackson, B.G. Rosenkranty 'Towards an unnatural history of inmunology', Journal of the History of Biology (1994), 27, 575-94. 
mouse embryo cells in $1963 .^{21}$ Popular in these days were other tissue culture systems, like the important for tumorigenic conversion lines of hamster kidney cells (designated BHK21). ${ }^{22}$ Or the C57BI strain of mouse, that was introduced by the French G. Barski (Institut Pasteur) ${ }^{23}$, the man who will participate his anticipations on oncogenic properties as early as $1968 .{ }^{24}$ Barski could be claimed priority in this early history of today widely used lab mouse strains as its first reviewer, in socialist Czechoslovakia journal Folia biologica. ${ }^{25} \mathrm{He}$ was also involved in the early essays of transfection. ${ }^{26}$ because of his reported formation of chromosomal hybrids by joint cultivation of two cell lines with morphological chromosomal markers. But unfortunately these in vitro and in vivo transformation experiments were not reproducible.

A given method in molecular genetics, the use for experimental results of $3 \mathrm{~T} 3$ cells is found to be in correspondence one-to-one with transfection essays. The work of the scientists who introduced their study is known only to others working in the field. The assumed concordance between diligence and viability that lies behind them varies inordinately from one case to another. ${ }^{27}$ As well as the amount of scientific work that they represent. In its real use, 3T3 cells are an uncertain form of the gradual process of neoplastic transformation in which a good number of genetics alterations are subjacent. It is what draws attention to the emphasis on these instruments. As such they

\section{Op. cit. (15).}

${ }^{22}$ L. Macpherson, M. Stoker, 'Polyoma transformation of hamster cell clones - an investigation, of genetic factors affecting cell competence', Virology (1962), 16, 147

${ }^{23}$ G. Barski, R. Cassingena, "Malignant transtormation in vitro of cells from C57BL mouse normal pulmonary tissue', $J$ Natl Cancer Inst. (1963), 30, 865-83,

${ }^{24} \mathrm{G}$. Barski, 'Evidence for oncogenic properties of heteroploid cell lines-discussion', Natl Cancer Inst Monogr (1968), 29, 289-90.

${ }^{25} \mathrm{G}$. Barski, "Recent acquisitions in malignant transformation of animal cells in vitro" Folia Biol (Praha) (1963 Oct), 54, 323-8.

${ }^{26}$ E.H. Szybalska, W. Szybalski, 'Genetics of human cell lines, IV. DNA-mediated heritable transformation of a biochemical trait', Proc. Natl. Acad. Sci. (1962), 48 2026-34.

${ }^{27}$ Even, there is a report suggesting at least two NLH $3 \mathrm{~T} 3$ cell lines of different origins circulating in the world. What makes depend on the cell lines tested, failures of identification of specific sets of genes in NIH 3 T3 cells. See, A. Iwamoto, M. Masuda H. Yoshikura "Two NIH3T3 cell lines of different origins circulating in the world", Jpn I Exp Med. (1985), 55, 129-31. need be ungovernable; the trial and error used to develop them is not the same as experimentation!

The outline of the analysis of this methodical testing device become a candidate to transcript the dialogues between those with the magnetic materialism to own it and those on which other priorities makes their use remarkably distinct. An interesting sidelight on this is that for a brief while the substantially active science is dominated by a lot of pieces of apparatus that could be connected with the use of these cell lines, and by the test procedures with which all manner of experiments could be done. ${ }^{28}$ This relationship between scientists and those who develop the instruments is a revealing example of the dialectical interaction of science and technology. As historically the arrow of causality is largely from the technology to the science.

\section{- SCIENTIFIC AGENDA OF Ángel PELlicer}

The Spanish immunological tradition, on the base of technical applications of these cells, started with J. Salas ${ }^{29}$ the doctoral advisor of M. Perucho, on DNA binding proteins from hamster fibroblasts, normal or transformed by oncogenic retroviruses. Salas was involved during his post-doctoral fellowship at NYU, in the early seventies, with $\mathrm{H}$ Green, the creator with GJ Todaro of this cell line."

In the middle eighties, Angel Pellicer research agenda is represented in Fig. $1 .^{31}$ The general topology of this picture differentiates the upper zone with the methods used along the researches, from the down zone with aims and results obtained. As observed by the use of

\footnotetext{
${ }_{28}$ Along this pioneer period, it is precisely the expression 'research front' that canonize the exploitation of technology by identification of it with the work of scientists.

${ }^{\text {to }}$ See R. Pollack, J. Salas, R. Wang, T. Kusano, H. Greell, 'Human-mouse hybrid cell lines and susceptibility to species-specific viruses', Journal of Cellwiar Physiology (1977), 77, 117-9; and J. Salas, H. Green, 'Proteins binding to DNA and their relation to growth in cultured mammalian cells', Nature: New biology (1971), 229, 165-9. 30 On the laboratory of Howard Green as where George Todaro developed the 3T3 lines, see G.W. Teebor, 'History of the Department of Pathology of the New York University School of Medicine', s. a.

${ }^{31}$ A maximum likelihood (ML) analysis was carried out with Treecloud, applying semantic proximity alrorithms, see P. Gambette, J. Véronis, 'Visualising a text with a Tree Clond" IFCS'OS: International Federation of Classification Sociaties Conference. 2009
} 
intensity in bold type, all the articles were the result of research supported by governmental programs.. Criteria of gene purification and cell-transformation observation on animals, like mice, served to experiment with mutations in oncogenes. Less highest intensity visualization of terms, as the corpus is associated with dates reflects superimposed information that reflects less disseminated researches. The structure of the tree is hidden in the center but the clades obtained at the two tips of the main branch substantially shows the chemics vs. radiation carcinogenic procedures.

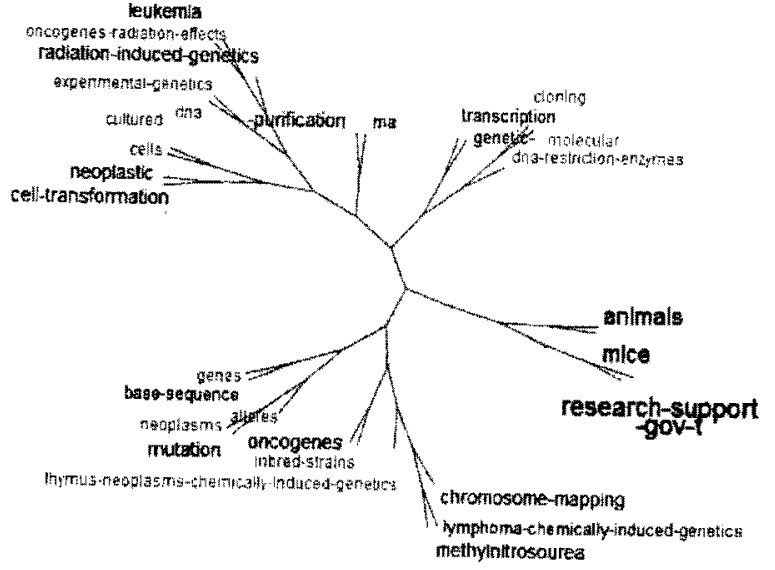

Figure 1. Maximum likelihood unrooted tree of the turnors scored positive and the genes responsible of it, diseovered by Angel Pellicer.

With Ángel Pellicer" it must be said that "until 1977, the methods of gene transfer were successful only when DNA of low complexity was used", and that "subsequent improvements made the transfer feasible using total vertebrate and mammalian". Pellicer's historical three viral positive timidine kinase colonies were obtained by using the mouse Ltk-cell line, one of the cell lines at this date that possessed exogene DNA incorporation and subsequent stabilization efficiency enough high to permit the gene transfer by using total

${ }^{32}$ See A. Pellicer, 'Gene purification by transfection methods', in R. Kucherlapaty (ed.), Gene transfer, New York: Plenum press, 1986, p. 264 (ref, in vid. nt. 35). cellular DNA, with the wiciencies reached by Michel Wigler modifications of the original method. The other line was NIH 3 T3. The experiment by Pellicer conclusively attained the theoretical efficiencies of the minimum value in need to transfer a single copy gene; in contrast with the first successes of the sixties this experiment was reproducible. And as such it was published in Cell, July 1978 issue. ${ }^{33}$

A result on gene transfer by using total mammalian DNA, that was obtained by Pellicer in the Columbia University in 1978. This genetic transformation of somatic cells attained its historical model in the exploration of the idea of cotransformation, ie the co-occurrence in transfer with relative high frequency of unselectable genes, together with a selectable one. ${ }^{34}$ That specifies in virtue of what property purified genes can be introduced in any kind of cultured cells. ${ }^{35}$

The next year, 1979, Perucho went to the Cold Spring Harbor Laboratory, from the Max Planck in Berlin. In the heat of the argument developed by Szybalski ${ }^{36}$ and through his involvement in the integration by cotransformation of all the donor cell genome into recipient chromosomes, the question of whether or not spontaneous neoplastic transformation of $3 \mathrm{~T} 3$ cells were responsible for unstability by transfection led to further analysis.

Created in the context of $3 \mathrm{~T} 3$ cells and at the same time, ${ }^{37}$ as a reference scenario for how experiments can "go", ${ }^{38} 3 \mathrm{~T} 6$ cells (a line

${ }^{33}$ M. Wigler, A. Pellicer, S. Silverstein, R. Axel, 'Biochemical transfer of single-copy eucaryotic genes using total cellular DNA as donor', Cell (1978), 14, Nr. 3, pp. 725-731.

${ }^{34}$ M. Wigler, R. Sweet, G.K. Sim, B. Wold, A. Pellicer, E. Lacy, T. Maniatis, S. Silverstein, R. Axel, "Transformation of manumalian cells with genes from procaryotes and eucaryotes", Cell (1979), 16, 777-85. This contribution was printed again, in 1992, as a historical article in the journal Biotechnology.

${ }^{3} \mathrm{M}$. Perucho, 'La transformación genética de eucariotas superiores y su infiuencia en el descubrimiento de los oncogenes humanos', in J. Casadesús, $F$. Ruiz Berraquero, (eds.) Descifrar la vida, Sevilla: Universidad, 1994, pp. 261-82

${ }^{36}$ In 1964, Szybalski reported, by working with a single cell derivative of the Detroit98 line, originally obrained by nonmalignant human sternal puncture that the mutant phenotype the obtention of maligne clones is determined by the tissular differentiation specific conditions See W. Szybalski. 'Chemical reactivity of hromosomal DNA as reloted to mutagenicity. studies with human cell lines', Cold ${ }^{7}$ Op. cit. (15), 303 . 
established by transfer of $3 \times 10^{5}$ cells to new capsules each six days), were used in $1980,{ }^{39}$ in an ongoing study of molecular genetics conducted since $1978^{40}$ at the Molecular Biology Center, Autonomous University in Madrid. The Jesús Ávila group worked in the characterization and analysis of the neuronal proteins associated to a component of the citoskeleton, the microtubules. ${ }^{41}$ The $3 T 6$ cell line was treated with the help in chromatin preparation of 1 . Guerrero. ${ }^{42}$

A SYSTEMIC INTERPRETATION OF THIS SCIENTIFIC COMMUNITY

A strictly increasing process define the cumulative monotonicity of scientific authority in terms of single-peakedness. It is what can fix the attention on the close competition in the race for oncogenes between the three core members of this Spanish community in US, Barbacid, Pellicer and Perucho. This relation between individual careers consist of being as source authors and as cited authors continually approached by the dynamics of the scientific community. A number of interacting processes can be advanced, each embedded in the next.

${ }^{38} \mathrm{~K}$. Knorr-Cetina, K. Amann, 'Image dissection in natural scientific inquiry', Science, Technolygy and Huncm Values (1990), 15, 259-83.

${ }^{39}$ A. Villasante, V.G. Corces, R. Manso-Martinez, J. Avila, 'Binding of microtubule protein to DNA and chromatin: possibility of simultaneous linkage of micrombule to nucleic-acid and assembly of the microtubule structure', Nucleic Acids Research (1981), 9, 895-908

${ }^{40}$ G. Wiche, V.G. Corces, J. Ávila, 'Preferential binding of hog brain microtubuleassociated proteins to mouse satellite versus bulk DN A preparations' Nature (1978), $273,403-5$.

"Microtubules associaced to neuroblastoma cell differentiation, otherwise useful for centromeric localization see human artificial chromosome ow gente http://www garfield library upenn edu/histcompthuman-atificial tromosomes 42 Non-histone proteins in this sequence of chromosomal regions, chromin (from melanogerer embryos), was her dissertation subject an the Autonomous Univerity ${ }^{43}$ See D.J. de S. Price 'Studies in se

'The relation between source ins', International Forum on Information and Documentation (Moscow) (1976), 1, 19-22

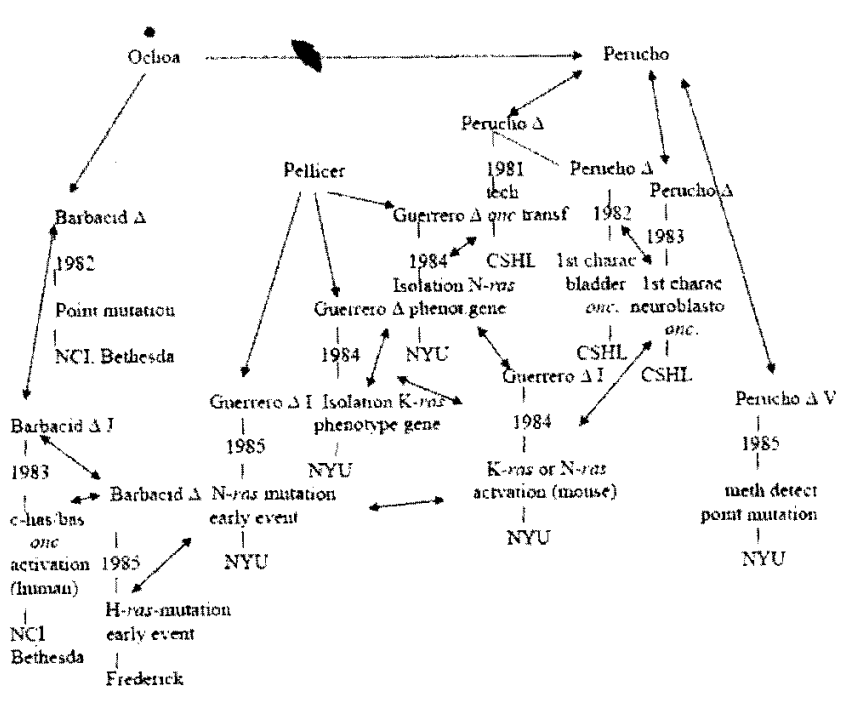

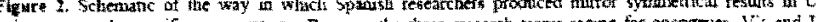

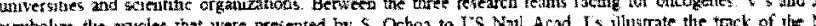

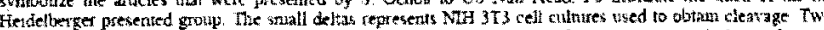

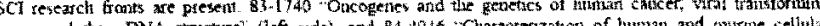
geaes and -

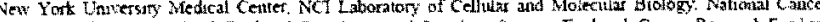

The scientific authority process, by defining it through the "cumulated" scientific authorities of a set of scientists, considers the "appropriated" assignation of authority, largely by defining the idea of research front. As such two research fronts are present here, 83-1740 "Oncogenes and the genetics of human cancer; viral transforming genes and their DNA structure", and 84-4046 "Characterization of human and murine cellular oncogene". ${ }^{4}$

Negative differences separate the three major groups of scientists that define the population of authors inside the program. It means that

${ }^{4}$ S. Fisher, Technical Support Representative ISI, Uxbridge, United Kingdom, 1994, personal communication. 
the problem requiring much more authority than they have assigned, continual competitive behaviour linked their productions.

On the question of how much affects individual scientists in this demography, or its constituent parts (groups of scientists), the fact is that only a woman (Guerrero) is allocated to treat the program. This knowledge must be described as an insularity that requres a distortion of the original structure before its narrative can be fitted neatly into place. ${ }^{45}$ Figure 2 provides a sketch of this social power process. ${ }^{45}$

\section{ONCOGENIC ORIGIN OF CANCER}

The potentially greater adversity of epigenetic alterations than nucleotide mutations (since their effects on regional chromatin structure can spread, thereby affecting multiple genetic loci) will gain the support of M. Heidelberger for Angel Pellicer contributions to the NAS. ${ }^{47}$ By associating his highly cited documents with the contexts where these citations occurred, is revealed the role of Pellicer as the transcriber, for both his friends (Barbacid and Perucho), of the "ownership" of the transfection experiments in the NIH 3 T3 cell lines. ${ }^{48}$

In fact as the mean life of a scientific publication is shorter as far as the literature growth is fast, the studies on oncogenes had grown up so much by 1993 , that new researchers were disengaging from the

${ }^{45}$ D.J. de S. Price, 'The development and structure of the biomedical literature', in K.S. Warren (ed.) Coping with the biomedical literature : a primer for the scientis and the clinician, Praeger, 1981, 3-16.

${ }^{4} \mathrm{M}$. Nowakowska, Theories of research, Seaside, California, Intersystems publications, 1984, 164-169, 'Reference frames'.

I. Guerrero, P. Calzada. A. Mayer, A. Pellicer, 'A molecular approach to leukemogenesis; mouse lymphonas contain an activated c-ras oncogene', Proc. Natl. Acad. Sci, USA (1984) 81, 202-5; I. Guerrero, A. Villasante, V. Corces, A. Pellicer, Loss of the normal $\mathrm{N}$-ras allele in a mouse thymic lymphoma induced by a chemical carcinogen', Proc. Natl, Acad. Sci. USA (1985), 82, 7810-4

Transfection started working at hands of Pellicer in 1977, see M. Wigler, S Silverstein, L.S. Lee, A. Pellicer. Y.C. Cheng, R. Axel, 'Transfer of purified Herpes virus thymidine kinase gene to cultured mouse ceils, Cell (1977), I1, 223-32. field. ${ }^{49}$ Figure 3 is then constructed until 1993, with the three Spanish racing teams citation data.

The 1984 Pellicer contribution "Isolation, characterization, and chromosome assignment of mouse $\mathrm{N}$-ras gene from carcinogeninduced thymic lymphoma" was clue in his work, as it suggested a unique role for the N-ras in mammals hematologic malignancies. Pellicer ascertained with this paper that the transmission of the modified N-ras gene followed Mendelian rules, and concluded that the absence of a ras gene might result in reduced levels of malignancy."

Both the 1983 Barbacid paper "Spontaneous activation of a human proto-oncogene" ${ }^{* 22}$ and the 1985 Perucho article "A method to detect and characterize point mutations in transcribed genes" ${ }^{\text {.5.3 }}$ were presented by the discoverer of RNA enzymatic synthesis (S.Ochoa) to the US NAS. They were signaled results from the labos of Barbacid at Bethesda and Perucho at Stony Brook, after well reported previous successes, ${ }^{54}$ and both used NIH $3 \mathrm{~T} 3$ cells to be driven to malignancy. Although Todaro found that NIH 3 T3 line is already heteroploid in chromosome constitution, ${ }^{55}$ as beginning

\footnotetext{
${ }^{19}$ J.L. Marx, 'Oncogenes reach a milestone', Science (1994), 266, 1942-4.

By the criticism of the number of citations that they received, we arrive to handle the main individual scientific papers described, so that their history become operationat.

${ }^{51}$ H. Umanoff, W. Edelmann, A. Pellicer, R. Kucherlapati, 'The murine N-ras gene is not essential for growth and development', Proc .Natl. Acad. Sci. USA (1995), 92, $1709-13$.

E. Santos, E.P. Reddy, S. Pulciani, R.J. Feldmann, M. Barbacid, 'Spontaneous activation of a human proto-oncogene', Proc. Nath. Acad. Sci. USA (1983), 80, 4679. 83. In 1982, both the groups of Mariano Barbacid and Eugenio Santos at the National Cancer Institute and of Michael Wigler and Manuel Perucho at the Cold Spring Harbor Laboratory found the oncogene of the T24 line of human bladder carcinoma

${ }_{53}$ E. Winter, F. Yamamoto, C. Almoguera. M. Perucho, 'A method to detect and characterize point mutations in transcribed genes: amplification and overexpression of the mutant C-Ki-ras allele in human tumorcells', Proc. Nati Acad SCi USA (1985). $82,7575-9$.

${ }_{54}$ J.L. Marx, (1982) 'Cancer cell genes linked to viral onc genes', Science (1982), 216, 724 .

${ }_{55}$ J.W. Littlefield, 'NIH 3 T3 Cell Line', Science $(1982), 218,214-6$
} 


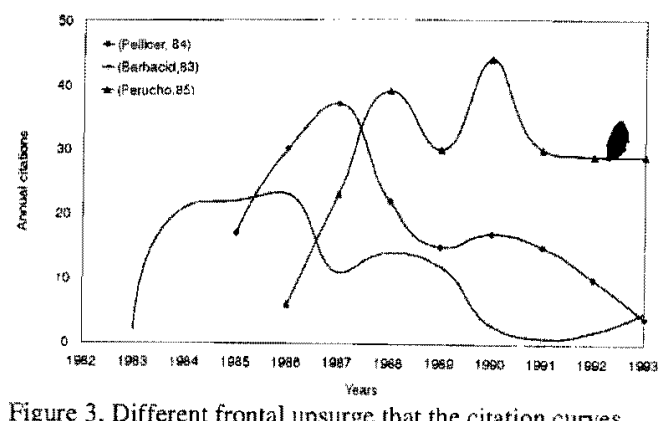

Figure 3. Different frontal upsurge that the citation curves provide in the three racing teams.

heteroploidy usually accompanies the initial event in the acquisition of transforming properties, NIH 3 T3 clones transformed by the mutant oncogenes on the human lung adenocarcinomas maintained in mice were homozygous for the mutant allele advanced Perucho. And Barbacid reported on an exception in an NIH 3T3 clone transformed by multiple copies of the c-has/bas proto-oncogenes, that successfully induced foci when tested in transfection assays.

As a real system of published research can be viewed like a sort of arboreal process, ${ }^{\text {st }}$ the relative autonomy of a team where the idiosyncrasy of a singular person (A. Pellicer) is prominent, holds with the assumption that his publications will show a special timewise progression. For a field that assemblages 9 contributions (see Table 1) when it is considered the felicitous choice of the ratio to the last five years in the references that they use (Price's Index), ${ }^{57}$ a guess can be made that this proportion range up to 75 percent in 8 of the cases. ${ }^{58}$ As

${ }^{56} \mathrm{R}$. Merton, 'Singletons and Multiples in Scientific Discovery : A Chapter in the Sociology of Science', in: American Philosophical Society, Proceedings 105, 1961 $470-486,483$.

for Prices reasoning, science as a whole looks to a very recent past of about 5 years for roughly half of all citations, see B.C. Griffith, 'Derek Price's puzzles : numerical metaphors for the operation of science', Science. Technology, \& Human Values 38 Price hazarded the

Price hazarded that for a "subject that was all research front and no gencral archive" a Price's Index range up to 75 percent, see D.J. de S. Price, "Citation measures of hard science, soft science, technology, and nonseience', in: E.N. Carnot, D. Pollack (eds.) the rate of growth of the literature is the vehicle for a field to estimate how is its activity, an estimation is made that the Pellicer contributions was about $88 \%$ all research front. Separately, a paper developed the comprehensiveness proper of the reviews (upper left corner, PI 73.52), as in fact it is no. 4 in a series entitled "Genetic mechanisms in tumour initiation and progression".

In Fig, 4, from the two more active papers (right side), there is a single best scored contribution (PI 92.3) to be ranged between the biochemistry discussions on the presence of point mutations in the ras genes; it acknowledged Ariel Ruiz i Altaba, from the Dpt. Cell Biology, NYU. The second position (lower right corner) comes from a contribution (PI 89.47) that could be close to an Ex Cathedra ${ }^{59}$ approach to the ras mutations immunogenetics. It was written by Angel Pellicer once I. Guerrero had returned to Europe (Oxford); - where she was working with Drosophila melanogaster, her doctoral dissertation subject and subsequent research field in Madrid.

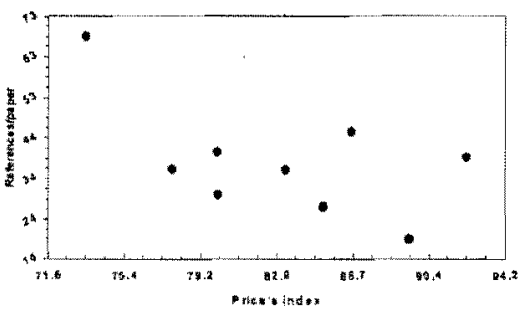

Figure 4. Scatter plot of share of Price indexes vs. number of references per paper.

As such, the appearance of 1 . Guerrero in this race keeps the characteristics of a research front worker. In the period, Pellicer two highly cited papers (scores 176,140 , see Table 1) were two studies dated in 1984. The first (PI 77.77), that supported the normative criteria of the US Natl Acad, was between the last presentations to the

Communication Among Scientists and Engineers, Lexington, Mass: Lexington Books, D.C. Heath and Company, 1970, 3-22.

J. Leon, I. Guerrero, A. Pellicer, 'Differential expression of the ras gene family in mice', Mol. Cell. Biol. (1987), 1535-40. Ex-Cathedra contributions are considered as with less than 16 references, op. cit. (58). 
NAS by M Heidelberger (1888-1991), the Ochoa colleague at the Harvey Society. ${ }^{60}$ So enhancing its value for the epigenetics of cancer. The interpretation must take in charge that this piece of work in an original way makes the choice of Maria Luisa Duran-Reynals between its sources. This Spanish bom medical doctor proviued excellent models for the genetic and epigenetic factors in lymphoid tumors working at Albert Einstein Medical School and at the laboratory facilities that had her husband, F. Duran-Reynals, at Yale. ${ }^{61}$

Table i: Histonical approach to the most recent past (5 years) of A.Pellicer 1984-88 comemibuions

\begin{tabular}{|c|c|c|c|}
\hline $\begin{array}{l}\text { Prist } \\
\text { Index }\end{array}$ & ar vef. & Mid-eighties A Pellicer sefected papers. & ar cit. \\
\hline 77.77 & 36 & 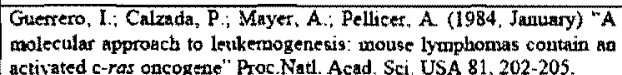 & 176 \\
\hline 85.18 & 27 & 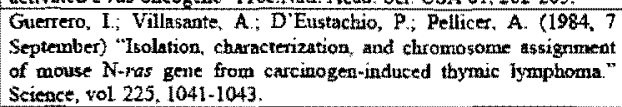 & 36 \\
\hline $\mathbf{8 3 , 3 3}$ & 36 & 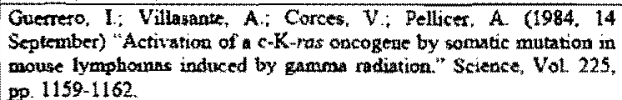 & 140 \\
\hline 92.3 & 39 & 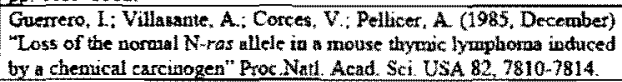 & $\overline{83}$ \\
\hline 80 & 40 & 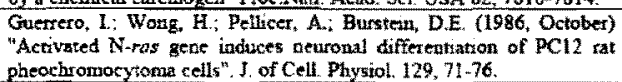 & 90 \\
\hline 86.6 & 45 & 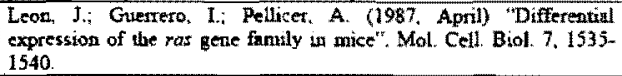 & 91 \\
\hline 73.52 & 68 & 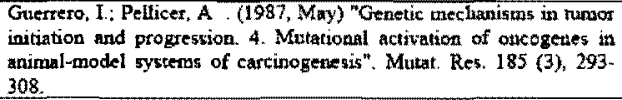 & 84 \\
\hline 80 & 30 & 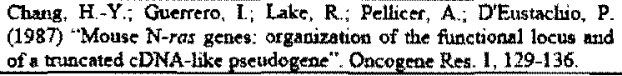 & 9 \\
\hline 89.47 & 19 & 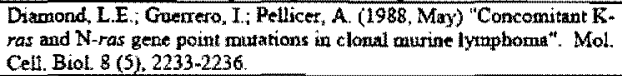 & 44 \\
\hline
\end{tabular}

${ }^{60}$ Ochoa was the 1953-54 Harvey Society President, and its 1952-53 Vice-President under the Presidency of the immunologist Heidelberger. See. The Harvey lectures: delivered under the auspices of the Harvey Society of New York 1977-1978. Academic Press, 1979, p. 321.

6. T.F. Glick, A Roca Rosell. 'Francesc Duran Reynals (Barcelona, 1899 - New Haven, USA, 1958). Virus and cancer: a controversial theory', Contributions to science (1999), 1, 87-98.
With a some less archival nature (PI 83.33) Pellicer contributed on oncogene mutations produced by $\gamma$-radiation, close to the chemically induced benign skin papillomas found activated $\mathrm{c}-\mathrm{K}$-ras and $\mathrm{N}$-ras. His discovery was that the alignment of the coding sequence from the isolated gene identified a single base change that produced an amino acid substitution. It came after Barbacid activation of $\mathrm{H}$-ras- $\mathrm{I}$ locus by single point mutation, and was conceived with the help of Perucho for the transfection of NIH 3 T 3 cells with recombinant plasmid.

\section{CONCLUSION}

The competing oncogene theory, of Robert Huebner and George Todaro, hypothesizing a genetic rather than an infectious mechanism for cancer, and Temin's evolutionary protovirus hypothesis were within the scope of the biology performed in Spain from the early seventies when José Salas was involved during his post-doctoral - fellowship at NYU, with $H$ Green, the creator with GJ Todaro of the NIH 3T3 cell line. Ángel Pellicer, whose doctoral advisor M.L. Salas was a close colleague of J Salas, worked 1976-80 in cell proliferation \& cancer at the Columbia University's Medical Center.

Transfection started working at hands of Pellicer in 1977. And two years later, in 1979, Pellicer communicated the protocols for transfection experiments to Mariano Barbacid, from the Laboratory of

RNA Tumor Viruses, NCI, Bethesda, and Manuel Perucho, from the Max Planck Institut für Molekulare Genetik (Berlin). Thus a friendship that started in Madrid along the doctorate in the early $70^{\circ} \mathrm{s}$ is linked to the creation of three research groups in molecular oncology, leadered by Spaniards in the US. As indeed the next year, in 1980, Angel Pellicer obtained a post as a teacher at the NYU Dpt. of Pathology, Perucho moved from Berlin to Cold Spring Harbor Laboratory and later to the Dpt. of Biochemistry, State University of New York at Stony Brook, and Barbacid created the Laboratory of cellular and molecular biology, in the National Cancer Institute (Bethesda).

Once they knew what they wanted from Pellicer, in 1979, how to make growth fibroblasts after successive transfer associated with malignant properties in vivo by using NIH 3T3 cells, all three molecular oncology research groups leadered by Spaniards decided to 
identify and isolate human oncogenes through the use of transfection identify and isolate human oncogenes through Mariano Barbacid and techniques. In 1982, both the groups of Mariano Barbacid and Wugenio Santos of the National Cancer Institute and Harbor Laboratory Wigler and Manuel Perucho of the Cold human bladder arcinoma cells. found the oncogene of the T24 line of human bladder ancinoma cells. And Pellicer decided to work in the identification and isolation of murine oncogenes also using transfecto 1980

NYU Dept of Pathology from 1980 .

This unifying concept of generic cell abnormaline To be true in determinant of cancer emerged from a specia cell triger cellu terms of exogenous and endogenous factors which do trigger celtula oncogenes the new carcinogen theory worked with a cell line (NIH 3T3) with a good number of genetic alterations subjacent to neoplastic transformation. In spite of the bias introduced in the analysis by the transfornatous amount of previous method of detecion, derived from the hazardous amount of previous infection behind NIH 3 T 3 cells, this selective controversy made them a revealing tool perceived as a frontier associated to malignan properties in vivo. Under the auspices of Pellicer, an answer was properties in the question on if it were the cultivated cells that activated provided to the question on if it were the cultived was operative in their gene after transfection while a different oncogen was operative in primary tumor cells. By suggesting a unique role for oncogene N-ras in mammals hematologic malignancies.

Together with his postdoc Guerrero, Pellicer debated whether or not oncogene mutations occur as the primary event in the development of the tumor. By providing additional evidences in favor of ras gene activation in early stages, Pellicer supplied robust support to the hypothesis that ras mutation is the primary event in carcinogenic models. He also reported on thymic lymphomas in favor of genetic models. He also reporion of ras genes with tumor arguments linking the mutated valaims that ras genes are activated by development and against clations and not by point mutation.

By working with brain mouse tumors, he provided definite evidence in favor of $\gamma$-radiation as a source of the first event that triggers the carcinogenic process. By way of consequence he crucially triggers the caring specificity for a carcinogen and intervened in the debate on mutation specificity for a carcinogen and
advanced the correlation between the activation of a particular oncogene and its expression in the target organ considering a preferred ras gene target for each experimental tumor analyzed.

The inestimable position of Spanish biologists, in touch with NIH 3 T3 cells from its inception, made them technically robust in the search for ras oncogenes. A medical doctor, Ángel Pellicer activated and characterized the genes involved in point mutations by using viral transforming genes obtained through transfer methods developed by him, first in Columbia University and later in the Dpt of Pathology, NYU. The responsibility for the initiation or progression of tumors, and the issues of mutation specificity have been his successful path to solve the dialectic between the chemist and the biologist in the first steps of molecular oncology. 